\title{
Pollen morphology and its taxonomic significance in the tribe Gochnatieae (Compositae, Gochnatioideae)
}

\author{
María C. Tellería · Gisela Sancho • Vicky A. Funk • \\ Iralys Ventosa $\cdot$ Nadia Roque
}

Received: 27 December 2012/ Accepted: 18 February 2013/Published online: 14 March 2013

(C) Springer-Verlag Wien 2013

\begin{abstract}
In the context of recent molecular phylogenies of the basal grades of Compositae, we investigated the utility of pollen morphology within the tribe Gochnatieae. The pollen of 64 species of Anastraphia, Cnicothamnus, Cyclolepis, Gochnatia, Pentaphorus, and Richterago was studied using light microscopy and scanning electron microscopy. In addition, three extra-Gochnatieae genera (Ianthopappus, Leucomeris, and Nouelia) were examined as they were traditionally morphologically related to members of the tribe Gochnatieae. Three of the species of Gochnatieae were examined using transmission electron microscopy. Two pollen types, and two new subtypes, have been recognized on the basis of the pollen shape, size, and exine sculpture. The pollen features of Gochnatia sect. Moquiniastrum and G. cordata are similar and distinctive
\end{abstract}

M. C. Tellería $(\square)$

Laboratorio de Sistemática y Biología Evolutiva, Museo de La

Plata, Paseo del Bosque s/n, B1900FWA La Plata, Argentina

e-mail: mariatelleria@fcnym.unlp.edu.ar

G. Sancho

División Plantas Vasculares, Museo de La Plata,

Paseo del Bosque s/n, B1900FWA La Plata, Argentina

V. A. Funk

US National Herbarium, Department of Botany, Smithsonian

Institution, 37012, MRC 166, Washington DC 20013-7012, USA

I. Ventosa

Vicedirección de Plantas Vasculares y Herbario Nacional, Instituto de Ecología y Sistemática, CITMA, Carretera Varona Km 3 1/2, Capdevila, Boyeros, AP 8029, CP 10800 Ciudad de la Habana, Cuba

N. Roque

Herbário Alexandre Leal Costa, Instituto de Biologia, Universidade Federal da Bahia, Campus Universitário de Ondina, Salvador, Bahia 40170-110, Brazil within the genus and support the recently re-circumscribed section Hedraiophyllum. Within the species with echinate pollen surface, the distinctive spine length of Anastraphia supports its recent resurrection as a genus. The identity of Pentaphorus could not be supported by pollen features as was for other morphological characteristics. The pollen features shared across Cyclolepis, Ianthopappus, Leucomeris, Nouelia and Gochnatia sect. Moquiniastrum, as well as those shared by Richterago and Anastraphia could be a result of parallel evolution.

Keywords Gochnatieae - Gochnatioideae - Compositae . Pollen $\cdot$ LM $\cdot$ SEM $\cdot$ TEM

\section{Introduction}

In the recent years, the basal grades of Compositae have been redefined to represent monophyletic groups based on molecular data (Panero and Funk 2002, 2008). According to the new perspective of the Compositae phylogeny, the circumscription of the tribe Mutisieae Cass. has been deeply modified from Cabrera's concept (Cabrera 1977). Now, groups of genera that once belonged to Mutisieae represent independent basal lineages circumscribed as tribes within new subfamilies. That is the case of Anastraphia D. Don, Cnicothamnus Griseb., Cyclolepis Gillies, Gochnatia Kunth, Pentaphorus D. Don, and Richterago Kuntze, which today constitute the tribe Gochnatieae Panero and Funk in the subfamily Gochnatioideae (Panero and Funk 2002). The Gochnatieae includes ca. 90 species of herbs, shrubs, subshrubs and trees which inhabit the Americas (Sancho and Freire 2009). The genus Gochnatia consists of ca. 36 species, most of them distributed in South America (Sancho and Freire 2009) and a few from southern 
USA and Mexico (Cabrera 1971); Anastraphia includes 32 species from the West Indies (Acevedo-Rodríguez and Strong $2007 \mathrm{http}: / /$ botany.si.edu/antilles/WestIndies/ acknowledgments.htm); Richterago includes 17 species that are endemic to Brazil (Roque and Pirani 2001); Cnicothamnus has two species from Argentina, Bolivia and Paraguay; Pentaphorus has two species from Western Argentina and Chile; and the monotypic Cyclolepis is found in Argentina and Paraguay. A key taxon of the tribe Gochnatieae is Gochnatia itself, which has been crucial to understand the basal grades of Compositae (Bremer 1994). Traditionally, the genus Gochnatia included six sections (Cabrera 1971): Discoseris (Endl.) Cabrera, Gochnatia (including Andean and Caribbean species), Hedraiophyllum (Less.) DC., Leucomeris (D. Don) Cabrera, Moquiniastrum Cabrera, and Pentaphorus (D. Don). DC. Later, Freire et al. (2002) published a rearrangement of Cabrera's sections based on an exhaustive morphological study. After recent taxonomic and molecular studies, four sections of Gochnatia (sensu Cabrera 1971 or sensu Freire et al. 2002) were recognized at the rank of genus: Anastraphioides S.E. Freire, G. Sancho and L. Katinas (including the Caribbean species), Discoseris, Leucomeris, and Pentaphorus. The section Anastraphioides was recognized as Anastraphia (Ventosa and Herrera 2011b). The section Discoseris and the genus Actinoseris were merged under Richterago, in agreement with that proposed by Roque and Pirani (2001). Leucomeris (that constituted the Asian Gochnatia sect. Leucomeris sensu Cabrera 1971), together with its closely related Asian genus Nouelia (Panero and Funk 2002), are today placed in the subfamily Wunderlichioideae. Pentaphorus (=Gochnatia sect. Pentaphorus sensu Cabrera 1971, and Freire et al. 2002) was placed in Gochnatieae (Hind 2007; Ortíz et al. 2009).

The pollen morphology of the tribe Gochnatieae and other members of Mutisieae sensu Cabrera (1977) has proven to be systematically and phylogenetically valuable (e.g., Lin et al. 2005; Zao et al. 2006; Tellería and Katinas 2004; Blackmore et al. 2009). However, the pollen of only some species of Gochnatieae has been studied. As part of a comparative pollen study within Mutisieae (sensu Cabrera 1977), Parra and Marticorena (1972) made a general characterization of the pollen of Gochnatia based on the examination of one species, G. foliolosa (D. Don) Hook. et Arn. (now Pentaphorus foliolosus). Roque and SilvestreCapelato (2001) studied the pollen morphology of four species of Gochnatia sect. Moquiniastrum and 14 species of Richterago. These authors also studied the pollen morphology of the monotypic Ianthopappus Roque and D.J.N. Hind, because it was, at that time, regarded closely related to Actinoseris (later Richterago) by Roque and Hind (2001). Zao et al. (2006) used scanning electron microscopy to examine the pollen morphology of Gochnatia argentina (Cabrera) Cabrera, G. curviflora (Griseb.) O. Hoffm., Cnicothamnus lorentzii Griseb., Nouelia insignis Franch., and Ianthopappus corymbosus (Less.) Roque and D.J.N. Hind (as Actinoseris corymbosa Less.). Katinas et al. (2008) made a general characterization of the pollen of Cnicothamnus lorentzii, Cyclolepis genistoides D. Don, and 20 species of Gochnatia as part of a monographic study of the subfamily Mutisioideae s.l. (mainly based on Cabrera's concept of the tribe Mutisieae, 1977). In that work, they recognized two main types of pollen on the basis of pollen size and the exine type. Recently, Blackmore et al. (2009) made a general pollen characterization of the tribe Gochnatieae as part of a broad study on Compositae and proposed an evolutionary sequence for the family. A few species of Gochnatieae, such as Pentaphorus foliolosus (as Gochnatia foliolosa, Parra and Marticorena 1972) and Cyclolepis genistoides (Tellería and Forcone 2002), are described in regional pollen floras. However, a thorough palynological study of the entire tribe Gochnatieae is still pending.

The new phylogenetic hypothesis of basal Compositae represents a change in the concept of the family. In this new framework, it is useful to discuss the diagnostic role of the pollen in basal groups. The goals of this study were to provide the first comprehensive study of the pollen of the Gochnatieae and determine whether the characters examined would help in defining the basal groups of the Compositae.

\section{Materials and methods}

Pollen from 64 species (104 specimens), representing all genera, and ca. $67 \%$ of the species of the tribe Gochnatieae have been examined ("Appendix"). For comparison, three extra-Gochnatieae genera, Ianthopappus, Leucomeris, and Nouelia, where included in the analysis. The specimens studied are deposited in the herbaria ALCB, C, G, HAC, HAJB, K, LP, S and US (Holmgren et al., http://sciweb.nybg.org/science2/IndexHerbariorum.asp). To achieve a complete comprehensive sample of Gochnatia pollen, species from all its sections (sensu Cabrera 1971) have been included independently if they have been recently recognized at the rank of genus (Panero and Funk 2008). Within Gochnatia as currently circumscribed, the names of the sections remaining in the genus follow Cabrera (1971) to facilitate the understanding of relationships among its species. Pollen was acetolyzed and chlorinated according to Erdtman (1960). For light microscopy (LM) slides were prepared by mounting the pollen in glycerol jelly and sealing with paraffin. Whenever possible, the polar $(P)$ and equatorial $(E)$ diameters of 25 grains were measured. The average and standard deviation were 
calculated when the total of measured grains was more than ten. The $P / E$ ratio was calculated for each specimen. The measurements of exine thickness are based on 15 grains. For scanning microscopy (SEM), acetolyzed pollen grains were suspended in $90 \%$ ethanol and mounted on stubs. The samples were sputter-coated with gold-palladium and examined in JEOL JSM T-100 and JEOL JSM 25 S-11. The terminology in general follows Punt et al. (2007); the characterization of Mutisia exine type was taken from Tellería and Katinas (2009); the size classification was taken from Erdtman (1969).

For transmission electron microscopy (TEM), the fresh pollen grains were fixed in $1.5 \%$ glutaraldehyde and then buffered $2 \% \mathrm{OsO}_{4}$ for $2 \mathrm{~h}$ at room temperature. After that, they were washed $30 \mathrm{~min}$ in distilled water and dehydrated in an ethanol series and finally embedded in acetone-Spurr 3:1 for $6 \mathrm{~h}$ and acetone-Spurr 1:1 for $16 \mathrm{~h}$ and twice in Spurr for $24 \mathrm{~h}$. Ultrathin sections were mounted in single grids and stained with lead citrate $(1 \mathrm{~min})$ and uranyl acetate $(10 \mathrm{~min})$. The examinations were made with a transmission electron microscope Jeol JEM 1200 EX II from the Servicio Central de Microscopía Electrónica of the Facultad de Ciencias Veterinarias, Universidad Nacional de La Plata.

\section{Results}

General pollen morphology

Pollen grains of all species examined are radially symmetrical and isopolar, spheroidal to prolate $(P / E=1-1.5)$, medium to large size, Gochnatia oligocephala has the smallest grain diameters $(P \times E=29-34 \mu \mathrm{m} \times 25-30 \mu \mathrm{m})$ and Anastraphia intertexta has the largest $(P \times E=$ 75-89 $\mu \mathrm{m} \times 52-70 \mu \mathrm{m})$ (Table 1); they are elliptic to circular in equatorial view (Fig. 1a-g) and triangular to circular in polar view (Figs. 1c, 2d, g). Pollen grains are 3-colporate with ecto-, meso-, and endoaperture. The colpi are long and acute (Fig. 4d) or blunt-ended (Fig. 5h), the colpus membrane is psilate (Fig. 4e) or scarcely microgranulate (Fig. 5e). The mesoaperture is usually diffuse (Fig. 4e). The endoaperture is always lalongate, sometimes with horns (Fig. 1a). The exine is tectate with echinate or microechinate surface (Fig. 3a-f). In echinate grains, the spines are uneven with acute or more or less rounded tips; spines are arranged in an uneven pattern as a whole (Fig. 3b, d). In the same grain, it is possible to observe areas with few and sparse spines and other areas where they are grouped. In microechinate grains, the microspines are conical or spiky shaped, commonly densely distributed (Fig. 3e, f). In Leucomeris spectabilis, the exine surface appears as microechinate rugulate (Fig. $5 \mathrm{~g}$ ). The exine is usually uniformly thickened in the complete grains, from 2- to $11-\mu \mathrm{m}$ thick (Figs. 1, 2), or it can be slightly or conspicuously thinned in subpolar or polar areas (e.g., G. vernonioides, G. arborescens, G. boliviana) (Fig. 1b, c). Thicker exines are usually associated with long spines. The sexine (or ectexine) consists of two layers of columellae separated by an internal tectum: the ecto- and endosexine, the ectosexine is finely columellate with a very perforate tectum, and the endosexine has thin or thick ramified columellae (Fig. 3c). The ectosexine may be equal, thinner or thicker than endosexine. The nexine (or endexine) is thickened in the area surrounding the endoaperture and underlying the colpi. Under TEM, pollen of different species (Fig. 6a-c). Endexine is commonly compact in the whole grains and lamellar in areas close to the apertures (Fig. 6a). The ectexine is composed of ectoectexine and endoectexine; both layers are separated by a conspicuous internal tectum which appears granulate. The endoectexine has robust and ramified columellae attached to a continuous foot layer. The ectoectexine has thinner and unramified columellae; non-homogenous material among columellae could be pollenkitt. Both spines and microspines have an apical channel. The tectum surface is interrupted by perforations excepting in L. spectabilis (Fig. 6c).

\section{Circumscription of pollen types and subtypes}

The most significant features to distinguish the pollen types and subtypes were: shape and size of the grains and sculpture of the exine. On the basis of these features, two pollen types and two subtypes were distinguished.

Key to pollen types and subtypes

\begin{tabular}{lll}
\hline 1 & Pollen predominantly echinate & Type I \\
$1^{\prime}$ & Pollen microechinate & 2 \\
2 & Pollen spheroidal-subprolate, always medium & Type II \\
& sized. Microspines conspicuous, conical or & Subtype a \\
& spiky & \\
$2^{\prime}$ & Pollen prolate to subprolate, generally large & Type II \\
& sized. Microspines, slightly distinguishable & Subtype b \\
& under LM & \\
\hline
\end{tabular}

Descriptions of pollen types

The description for each pollen type and subtype outlines the shared features of the pollen from all species includes in that pollen type or subtype.

Type I (Figs. 1, 4): Pollen generally prolate to subprolate except Anastraphia obtusifolia which is subprolatespheroidal (Table 1), elliptic in equatorial view, and subcircular or triangular in polar view. Exine echinate, 
Table 1 Pollen of examined Gochnatieae and related genera showing measurements of polar $(P)$ and equatorial diameters $(E)$ with the average $(X)$ and standard deviation $(\delta), P / E$ ratio, exine thickness at the poles $(P)$ and equator $(E)$, and pollen type

\begin{tabular}{|c|c|c|c|c|c|c|c|c|}
\hline Taxa & $P(\mu \mathrm{m})$ & $X(\delta)$ & $E(\mu \mathrm{m})$ & $X(\delta)$ & $P / E$ & Exine $(P)$ & Exine $(E)$ & Pollen type \\
\hline Cnicothamnus lorentzii $^{(\mathrm{a})}$ & $66-77$ & $75(4)$ & $50-54$ & $54(3)$ & Prolate & $8-9$ & $8-9$ & I \\
\hline Cyclolepis genistoides $^{(\mathrm{a})}$ & $36-43$ & $43(2)$ & $31-38$ & $34(2)$ & Spheroidal-subprolate & $5-6$ & $4-7$ & IIa \\
\hline Anastraphia attenuata ${ }^{(\mathrm{a})}$ & $38-42$ & $40(1)$ & $35-39$ & $40(1)$ & Spheroidal & $4-5$ & $4-5$ & $\mathrm{IIa}$ \\
\hline A. attenuata $^{(\mathrm{b})}$ & $41-49$ & $48(5)$ & $33-39$ & $38(2)$ & Spheroidal & $5-7$ & $6-8$ & IIa \\
\hline A. buchii $^{\text {(a) }}$ & $47-52$ & $49(1)$ & $31-40$ & $35(3)$ & Prolate & $5-6$ & $5-6$ & I \\
\hline A. buchii ${ }^{(\mathrm{b})}$ & $44-54$ & $51(2)$ & $33-40$ & $38(2)$ & Subprolate-prolate & $6-7$ & $5-7$ & I \\
\hline A. calcicola & $67-78$ & $71(5)$ & $50-64$ & $57(4)$ & Subprolate-prolate & $8-10$ & $7-11$ & I \\
\hline A. cowellii $^{\text {(a) }}$ & $66-78$ & $69(3)$ & $47-57$ & $52(3)$ & Subprolate & $8-9$ & $8-9$ & I \\
\hline A. crassifolia & $48-64$ & $55(5)$ & $43-49$ & $45(2)$ & Subprolate & $7-10$ & $7-10$ & I \\
\hline A. cubensis & $59-68$ & $62(3)$ & $37-49$ & $40(3)$ & Subprolate-prolate & $7-10$ & $7-8$ & I \\
\hline A. ekmanii ${ }^{\text {(a) }}$ & $51-69$ & $63(5)$ & $41-48$ & $45(2)$ & Prolate & $6-8$ & $7-9$ & I \\
\hline A. elliptica & $51-59$ & $55(2)$ & $32-40$ & $36(2)$ & Prolate & $7-9$ & $7-9$ & I \\
\hline A. gomezii & $54-62$ & $58(2)$ & $37-43$ & $39(1)$ & Prolate & $6-7$ & $6-8$ & I \\
\hline A. northropiana $^{(\mathrm{a})}$ & $34-46$ & $41(3)$ & $29-36$ & $33(2)$ & Suprolate-prolate & $5-6$ & $5-6$ & I \\
\hline A. intertexa & $75-89$ & $82(3)$ & $52-70$ & $58(4)$ & Subprolate-prolate & $8-13$ & $10-12$ & I \\
\hline A. maisiana & $49-65$ & $56(1)$ & $38-45$ & $39(1)$ & Subprolate-prolate & $6-8$ & $7-10$ & I \\
\hline A. mantuensis ${ }^{(\mathrm{a})}$ & $46-58$ & 49 & $39-44$ & 41 & Subprolate & $6-10$ & $7-9$ & I \\
\hline A. mantuensis ${ }^{(\mathrm{b})}$ & $53-65$ & $61(4)$ & $36-43$ & $42(3)$ & Prolate & $5-8$ & $6-8$ & I \\
\hline A. montana & $55-61$ & $57(1)$ & $48-46$ & $44(2)$ & Subprolate-prolate & $7-9$ & $7-10$ & I \\
\hline A. obovata & $43-74$ & $64(9)$ & $41-55$ & $48(5)$ & Prolate & $6-8$ & $8-9$ & I \\
\hline A. obtusifolia & $48-56$ & $52(3)$ & $38-45$ & $44(3)$ & Subprolate-spheroidal & $6-10$ & $7-10$ & I \\
\hline A. parvifolia & $53-60$ & $56(2)$ & $39-45$ & $43(2)$ & Subprolate-prolate & $7-9$ & $6-9$ & I \\
\hline A. pauciflosculosa & $49-59$ & $55(3)$ & $33-45$ & $38(4)$ & Prolate & $5-7$ & $5-7$ & I \\
\hline A. picardae & $57-65$ & $62(2)$ & $39-46$ & $44(2)$ & Prolate & $5-8$ & $7-9$ & I \\
\hline A. recurva $^{(\mathrm{a})}$ & $55-66$ & $59(3)$ & $44-48$ & $46(1)$ & Subprolate-prolate & $7-9$ & $8-10$ & I \\
\hline A. $\operatorname{recurva}^{(\mathrm{b})}$ & $48-55$ & $55(2)$ & $38-44$ & $43(2)$ & Subprolate-prolate & $7-8$ & $7-9$ & I \\
\hline A. ilicifolia $^{(\mathrm{a})}$ & $56-71$ & $66(5)$ & $45-57$ & $51(4)$ & Subprolate-prolate & $6-10$ & $7-10$ & I \\
\hline A. ilicifolia $^{(\mathrm{b})}$ & $78-81$ & $83(3)$ & $56-61$ & $61(4)$ & Subprolate-prolate & $7-10$ & $7-10$ & I \\
\hline A. shaferi & $55-62$ & $58(2)$ & $36-43$ & $40(2)$ & Subprolate-prolate & $7-8$ & $8-9$ & I \\
\hline A. tortuensis & $40-48$ & $54(3)$ & $38-52$ & $43(3)$ & Subprolate-prolate & $7-9$ & $7-10$ & I \\
\hline \multicolumn{9}{|l|}{ Gochnatia } \\
\hline \multicolumn{9}{|l|}{ Section Gochnatia } \\
\hline G. arequipensis & $53-65$ & $59(3)$ & $39-47$ & $44(2)$ & Subprolate-prolate & $8-11$ & $7-9$ & I \\
\hline G. boliviana ${ }^{(\mathrm{a})}$ & $41-61$ & $57(5)$ & $40-46$ & $43(2)$ & Subprolate-prolate & $8-11$ & $7-9$ & I \\
\hline G. boliviana ${ }^{(\mathrm{b})}$ & $52-56$ & $54(2)$ & $39-45$ & $42(2)$ & Subprolate-prolate & $6-7$ & $8-9$ & I \\
\hline G. curviflora & $48-57$ & $53(2)$ & $41-48$ & $44(2)$ & Subprolate & $7-10$ & $6-7$ & I \\
\hline G. patazina & $57-64$ & $61(2)$ & $42-47$ & $44(1)$ & Prolate & $8-11$ & $8-10$ & I \\
\hline G. rotundifolia ${ }^{(\mathrm{a})}$ & $45-56$ & $50(3)$ & $37-45$ & $42(3)$ & Subprolate & $5-7$ & $5-7$ & I \\
\hline G. vernonioides ${ }^{(\mathrm{a})}$ & $53-61$ & $57(2)$ & $41-45$ & $43(2)$ & Subprolate-prolate & $7-9$ & $7-10$ & I \\
\hline \multicolumn{9}{|l|}{ Section Hedraiophyllum } \\
\hline G. arborescens & $47-60$ & $55(3)$ & $42-48$ & $45(2)$ & Subprolate & $7-10$ & $8-10$ & I \\
\hline G. cordata $^{(\mathrm{a})}$ & $37-48$ & $43(4)$ & $34-43$ & $37(2)$ & Subprolate-spheroidal & $5-8$ & $5-7$ & IIa \\
\hline G. cordata $^{(\mathrm{b})}$ & $38-41$ & $39(1)$ & $34-36$ & $35(1)$ & Subprolate-spheroidal & $4-5$ & $4-5$ & IIa \\
\hline G. magna & $51-57$ & $54(2)$ & $39-40$ & $42(2)$ & Prolate & $7-8$ & $8-8.5$ & I \\
\hline G. palosanto ${ }^{(\mathrm{a})}$ & $39-49$ & $46(3)$ & $29-34$ & $33(2)$ & Subprolate-prolate & $5-8$ & $6-7$ & IIa \\
\hline G. palosanto ${ }^{(\mathrm{b})}$ & $48-56$ & $53(2)$ & $40-44$ & $42(1)$ & Subprolate-prolate & $7-8$ & $7-8$ & $\mathrm{IIa}$ \\
\hline
\end{tabular}


Table 1 continued

\begin{tabular}{|c|c|c|c|c|c|c|c|c|}
\hline Taxa & $P(\mu \mathrm{m})$ & $X(\delta)$ & $E(\mu \mathrm{m})$ & $X(\delta)$ & $P / E$ & Exine $(P)$ & Exine $(E)$ & Pollen type \\
\hline \multicolumn{9}{|l|}{ Section Moquiniastrum } \\
\hline G. argyrea & $31-44$ & $36(4)$ & $28-36$ & $32(3)$ & Subprolate & $4-5$ & $4-5$ & IIa \\
\hline G. barrosoae $e^{(\mathrm{a})}$ & $32-37$ & $35(2)$ & $29-33$ & $31(1)$ & Spheroidal-subprolate & $4-5$ & $4-5$ & IIa \\
\hline G. barrosoae ${ }^{(\mathrm{b})}$ & $29-33$ & $32(1)$ & $27-32$ & $30(2)$ & Spheroidal & $3-5$ & $3-4$ & IIa \\
\hline G. blanchetiana & $30-38$ & & $26-32$ & & Subprolate & 2.4 & 2.4 & IIa \\
\hline G. densicephala ${ }^{(\mathrm{a})}$ & $31-37$ & $33(1)$ & $28-33$ & $30(1)$ & Spheroidal & $4-5$ & $3-5$ & IIa \\
\hline G. densicephala ${ }^{(\mathrm{b})}$ & $35-38$ & $38(2)$ & $26-32$ & $28(1)$ & Subprolate & $3-4$ & $4-5$ & IIa \\
\hline G. discolor & $32-42$ & $37(2)$ & $29-34$ & $32(2)$ & Spheroidal-subprolate & $3-4$ & $3-5$ & IIa \\
\hline$G$. floribunda & $33-42$ & $38(2)$ & $26-31$ & $28(1)$ & Subprolate & 4 & 4 & IIa \\
\hline G. gardneri & $29-38$ & $33(3)$ & $26-36$ & $29(2)$ & Spheroidal-subprolate & $3-5$ & $4-6$ & IIa \\
\hline G. hatschbachii & $30-31$ & & $33-34$ & & Spheroidal & $3-4$ & $3-4$ & IIa \\
\hline G. haumaniana & $32-36$ & & $25-29$ & & Spheroidal-subprolate & 2.4 & 2.4 & IIa \\
\hline G. oligocephala ${ }^{(a)}$ & $29-34$ & $31(2)$ & $25-30$ & $27(1)$ & Spheroidal & 2 & 2 & IIa \\
\hline G. oligocephala ${ }^{(\mathrm{b})}$ & $28-39$ & $36(2)$ & $27-34$ & $29(1)$ & Subprolate & 3 & $3-5$ & IIa \\
\hline G. orbiculata & $30-39$ & $35(3)$ & $29-34$ & $31(2)$ & Spheroidal-subprolate & $3-4$ & $3-4$ & IIa \\
\hline G. polymorpha ${ }^{(\mathrm{a})}$ & $27-32$ & $29(1)$ & $25-30$ & $28(1)$ & Spheroidal & $3-4$ & $3-4$ & IIa \\
\hline G. polymorpha ${ }^{(\mathrm{b})}$ & $29-28$ & $33(3)$ & $42-33$ & $28(1)$ & Spheroidal & $3-6$ & $3-6$ & IIa \\
\hline G. ramboi & $34-38$ & $36(2)$ & $27-34$ & $30(2)$ & Spheroidal & 4 & 4 & IIa \\
\hline \multicolumn{9}{|l|}{ Section Pentaphorus } \\
\hline Pentaphorus glutinosus $^{(\mathrm{a})}$ & $45-52$ & $48(2)$ & $32-40$ & $36(2)$ & Subprolate-prolate & $5-6$ & $5-7$ & $\mathrm{I}$ \\
\hline P. glutinosus $^{(\mathbf{b})}$ & $48-60$ & $53(3)$ & $38-55$ & $41(4)$ & Subprolate-prolate & $7-8$ & $8-10$ & I \\
\hline P. foliolosus ${ }^{(\mathrm{a})}$ & $42-51$ & 46 & $34-37$ & 35 & Prolate & $6-9$ & $6-7$ & I \\
\hline P. foliolosus ${ }^{(\mathrm{b})}$ & $47-52$ & & $33-37$ & & Prolate & 5 & $6-7$ & I \\
\hline Lanthopappus corymbosus & $47-59$ & $53(4)$ & $46-57$ & $51(3)$ & Subprolate & $6-10$ & $6-8$ & I \\
\hline Leucomeris spectabilis $^{(a)}$ & $45-57$ & $52(3)$ & $30-42$ & $38(2)$ & Subprolate & 5 & 5 & $\mathrm{IIb}$ \\
\hline Nouelia insignis ${ }^{(a)}$ & $68-79$ & $74(3)$ & $41-52$ & $46(1)$ & Prolate & $7-9$ & $6-8$ & $\mathrm{IIb}$ \\
\hline Nouelia insignis $^{(\mathrm{b})}$ & $62-67$ & & $42-48$ & & Prolate & $7-8$ & $7-8$ & $\mathrm{IIb}$ \\
\hline Richterago amplexifolia & $45-51$ & $49(2)$ & $38-43$ & $40(1)$ & Spheroidal-subprolate & $6-9$ & $7-10$ & I \\
\hline R. angustifolia & $44-48$ & & $35-39$ & & Subprolate-prolate & $6-8$ & $7-8$ & I \\
\hline$R$. arenaria & $45-53$ & & $35-41$ & & Subprolate-prolate & $6-9$ & $8-9$ & I \\
\hline R. caulescens $^{(\mathrm{a})}$ & $48-57$ & & $40-48$ & & Subprolate-prolate & $7-8$ & $7-8$ & I \\
\hline R. conduplicata & $47-52$ & $49(1)$ & $38-46$ & $41(1)$ & Subprolate-prolate & $7-8$ & $7-8$ & I \\
\hline R. discoidea ${ }^{(\mathrm{a})}$ & $44-53$ & $48(2)$ & $37-44$ & $40(2)$ & Subprolate & $6-9$ & $8-10$ & I \\
\hline R. discoidea ${ }^{(\mathrm{b})}$ & $41-47$ & & $32-38$ & & Subprolate & $5-6$ & $5-8$ & I \\
\hline R. elegans & $55-44$ & $49(4)$ & $41-34$ & $38(3)$ & Subprolate-prolate & $5-7$ & $6-8$ & I \\
\hline R. polyphylla & $41-48$ & $46(3)$ & $33-40$ & $35(2)$ & Subprolate-prolate & $5-8$ & $6-8$ & I \\
\hline R. stenophylla & $45-50$ & $50(3)$ & $20-41$ & $41(3)$ & Subprolate-prolate & $6-7$ & $7-8$ & I \\
\hline R. radiata $^{(\mathrm{a})}$ & $43-53$ & $49(3)$ & $33-41$ & $35(2)$ & Subprolate-prolate & $6-9$ & $7-9$ & I \\
\hline R. radiata $^{(\mathrm{b})}$ & $45-51$ & $47(1)$ & $35-36$ & $37(1)$ & Subprolate-prolate & $5-7$ & $7-8$ & I \\
\hline
\end{tabular}

(a), (b) Refer to collecting data (see "Appendix")

commonly equally thickened in the complete grain, sometimes conspicuously reduced at the polar or subpolar areas. Spines unevenly distributed; the pollen surface among the spines is very perforate forming a delicate microreticulum, sometimes with striate aspect (seen only in SEM) (Fig. 3b). Species included: Anastraphia (A. buchii, A. calcicola, A. cowelli, A. crassifolia, A. cubensis,
A. ekmanii, A. elliptica, A. gomezii, A. ilicifolia, A. intertexta, A. magna, A. maisiana, A. mantuensis, A. montana, A. northropiana, A. obtusifolia, A. parvifolia, A. pauciflosculosa, A. picardae, A. recurva, A. shaferi, A. tortuensis), Cnicothamnus lorentzii, Gochnatia sect. Gochnatia (G. arequipensis, G. boliviana, G. curviflora, G. patazina, G. rotundifolia, G. vernonioides), Gochnatia sect. 


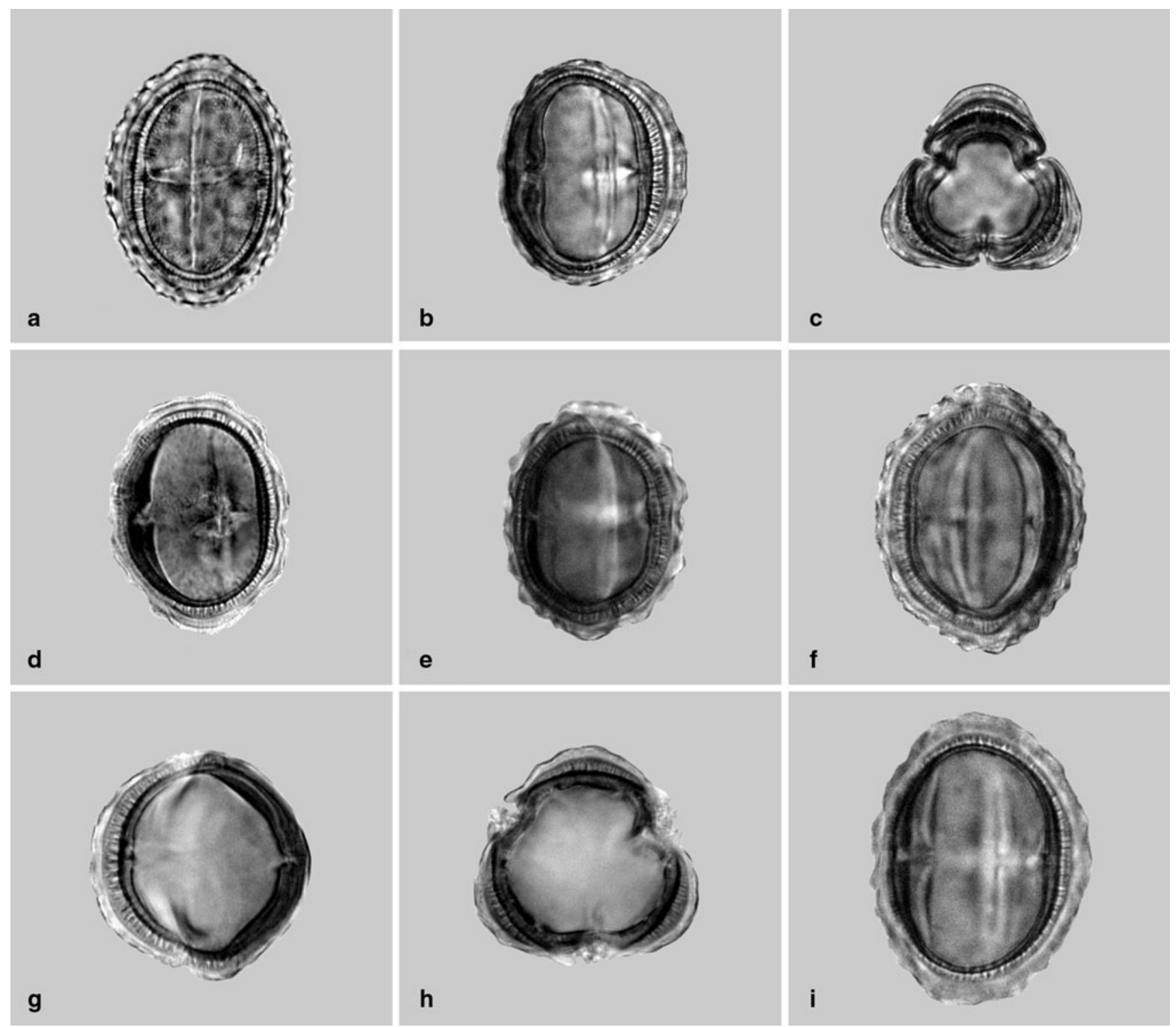

Fig. 1 LM micrographs of whole grains at different focus level in some species comprised in the Type I showing the shape in equatorial and polar view, the exine thickness, and some apertural features. a Cnicothamnus lorentzii, equatorial view showing the endoaperture with horns. b, c Gochnatia arborescens. b Equatorial view showing the exine thinned toward the poles. $\mathbf{c}$ Polar outline triangular-shaped.

Hedraiophyllum (G. arborescens, G. palosanto), Ianthopappus corymbosus, Pentaphorus ( $P$. foliolosus and P. glutinosus), Richterago amplexifolia, $R$. angustifolia, $R$. arenaria, $R$. caulescens, $R$. conduplicata, $R$. discoidea, $R$. elegans, $R$. polyphylla, $R$. radiata, and $R$. stenophylla. Note that pollen of some of these species, especially those of the Caribbean Anastraphia, Gochnatia magna, and Cnicothamnus lorentzii, have longer spines comparing to those of the remaining species included in this type (Table 1). This pollen type may include pollen grains with polar and/or equatorial exine thickening; however, this feature was variable among specimens and in pollen grains d Anastraphia calcicola, equatorial view showing the exine equally thickened in the complete grain. e. Pentaphorus foliolosus, equatorial view. f Anastraphia tortuensis, equatorial view showing the exine slightly thickened at the poles. $\mathbf{g}$, h Ianthopappus corymbosus. g Equatorial view. h Polar outline subcircular-shaped. i Richterago polyphylla, equatorial view. Scale bars $10 \mu \mathrm{m}$

of the same specimens in $G$. arborescens, G. arequipensis, and $G$. vernonioides (Figs. 1b, 4b).

Type II. (Figs. 2, 5): Pollen grains prolate to spheroidal, elliptic or spheroidal in equatorial view, circular in polar view. Exine microechinate. Subtype IIa: The grains are medium-sized, spheroidal to subprolate, and their microspines are conical or spiky, the tectum is scarcely perforated (in SEM). This type of pollen is present in: Anastraphia attenuata, Cyclolepis genistoides, Gochnatia cordata, and G. sect. Moquiniastrum (G. argyrea, G. barrosoae, G. densicephala, G. discolor, G. floribunda, G. gardneri, G. hatschbachii, G. oligocephala, G. orbiculata, G. paniculata, 


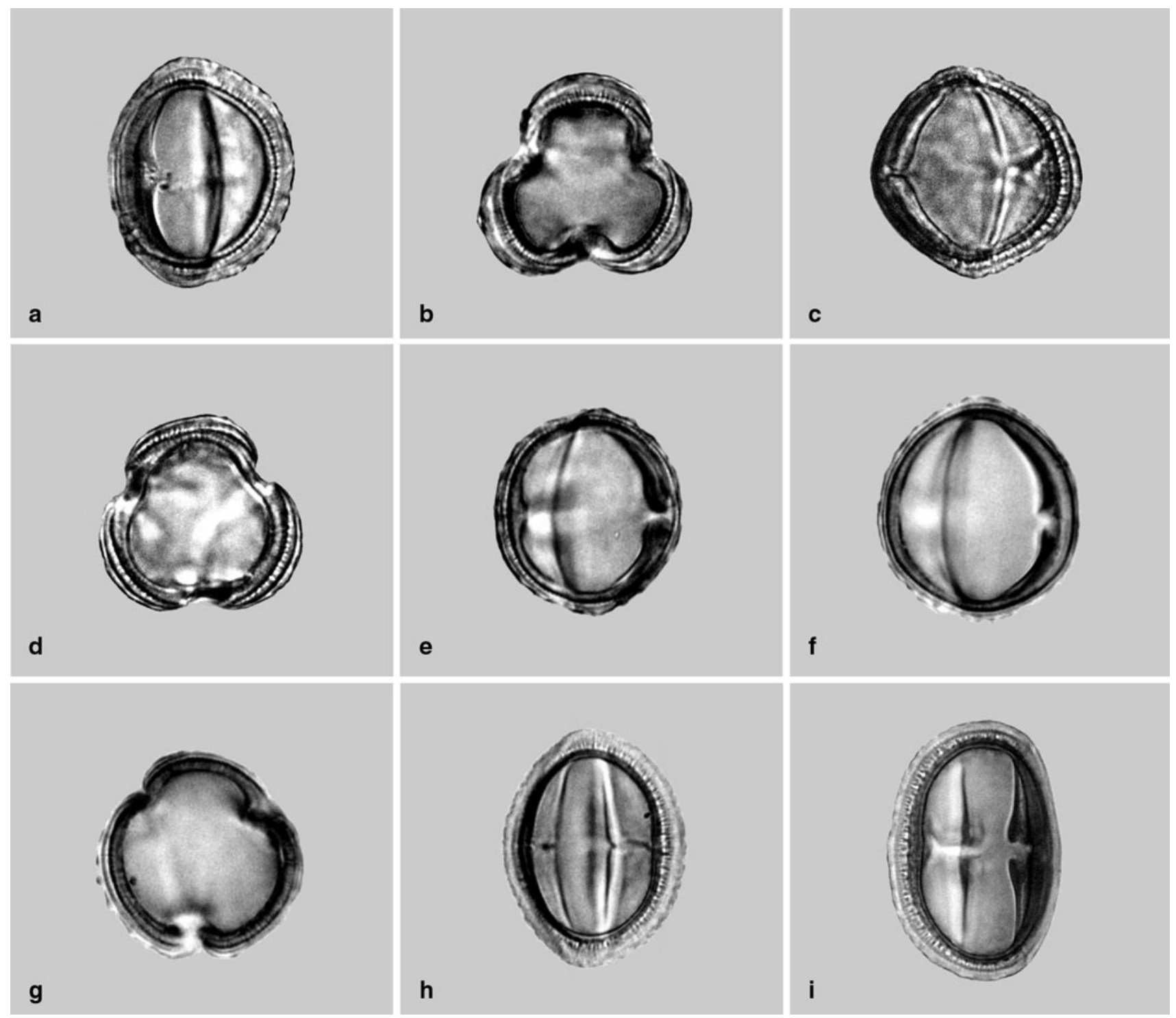

Fig. 2 LM micrographs of whole grains at different focus level in some species of Gochnatieae and allied genera comprised in the Type II, subtypes IIa and IIb showing the shape in equatorial and polar view and the exine thickness. Subtypes IIa. a, b Cyclolepis genistoides. a Equatorial view. b Polar view. c, d Gochnatia barrosoae.

G. polymorpha, and G. ramboi). Subtype IIb: Large pollen grains are rarely medium-sized, prolate to subprolate shaped, with microspines slightly distinguishable under LM. The tectum surface is scarcely perforated (in SEM) (Fig. 3e). Present in L. spectabilis, and Nouelia insignis.

\section{Discussion}

General features of the pollen of Gochnatieae

Our results on the pollen morphology of the tribe Gochnatieae are not in conflict with previous contributions c Equatorial view. d Polar view. e G. cordata, equatorial view. f, g $G$. haschbachii. f Equatorial view. g Polar view. Subtypes IIb. h Leucomeris spectabilis, equatorial view. i Nouelia insignis, equatorial view. Scale bars $10 \mu \mathrm{m}$

(Roque and Hind 2001; Ventosa and Herrera (2011a; Katinas et al. 2008). However, the examination of the pollen of these 104 specimens across the tribe and some of its traditionally morphologically related genera demonstrated that the patterns of variation in the pollen morphology are a little more complex than that previously thought for the tribe. For instance, the pollen of all studied species accommodated in the two broad types here defined on the basis of pollen size and exine features (Katinas et al. 2008), but, at the same time, we observed enough variation within Type II to recognize two new subtypes. In addition, the pollen types and subtypes not always correspond with the current taxonomic limits of the genera of Gochnatieae. 

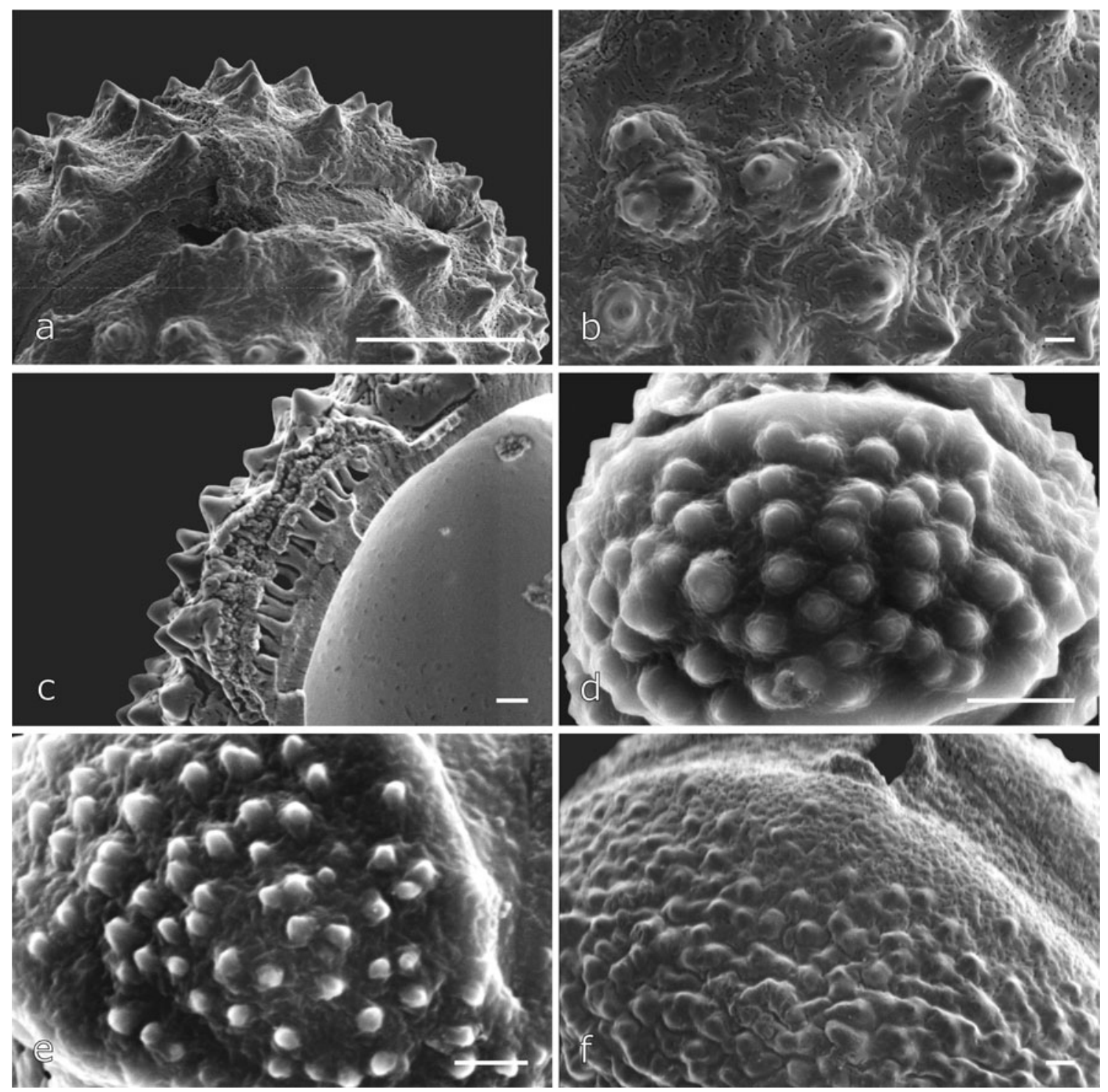

Fig. 3 SEM micrographs of exine features. a-c Anastraphia montana. a Pollen surface showing the spines and the psilate apertural membrane. b Detail of perforate tectum, note the striate aspect. c Fractured pollen showing the exine stratification. d Richterago

The exine surface (and to a lesser extend, the structure), and both size and shape in equatorial view of grains studied appear to be more useful to distinguish pollen types and subtypes. In addition, some correlation was found among these characters. The pollen belonging to Type I, here described, combines echinate surface with very perforate tectum, large grain size and commonly prolate-subprolate shape. These features are characteristic of Cnicothamnus lorentzii, species of both Anastraphia and Gochnatia (mainly from section Gochnatia), the monotypic Ianthopappus, and ten species of Richterago. The exine surface features of pollen Type I clearly correspond to the Wunderlichia exine type (Katinas et al. 2008). However, discoidea, pollen surface showing uneven spines. e Gochnatia oligocephala showing conical microspines. f Leucomeris spectabilis showing the microechinate-rugulate surface. Scale bars $\mathbf{a} 10 \mu \mathrm{m}, \mathbf{b}, \mathbf{c}$, f $1 \mu \mathrm{m}, \mathbf{d} 5 \mu \mathrm{m}$, e $2 \mu \mathrm{m}$

the uneven echinate pollen surface is a remarkable feature in this group. In fact, microspines are very commonly arranged among the long spines, which frequently make the determination that whether the sculpture is echinate or microechinate difficult.

Gochnatia rotundifolia was placed by Cabrera (1971) in the section Gochnatia although later it was transferred to the new section Rotundifolia S.E. Freire, G. Sancho \& Katinas (2002). The pollen evidence did not support the distinctiveness of $G$. rotundifolia shown by other morphological characters as its pollen features are similar to those found in many other representatives of Gochnatia. 

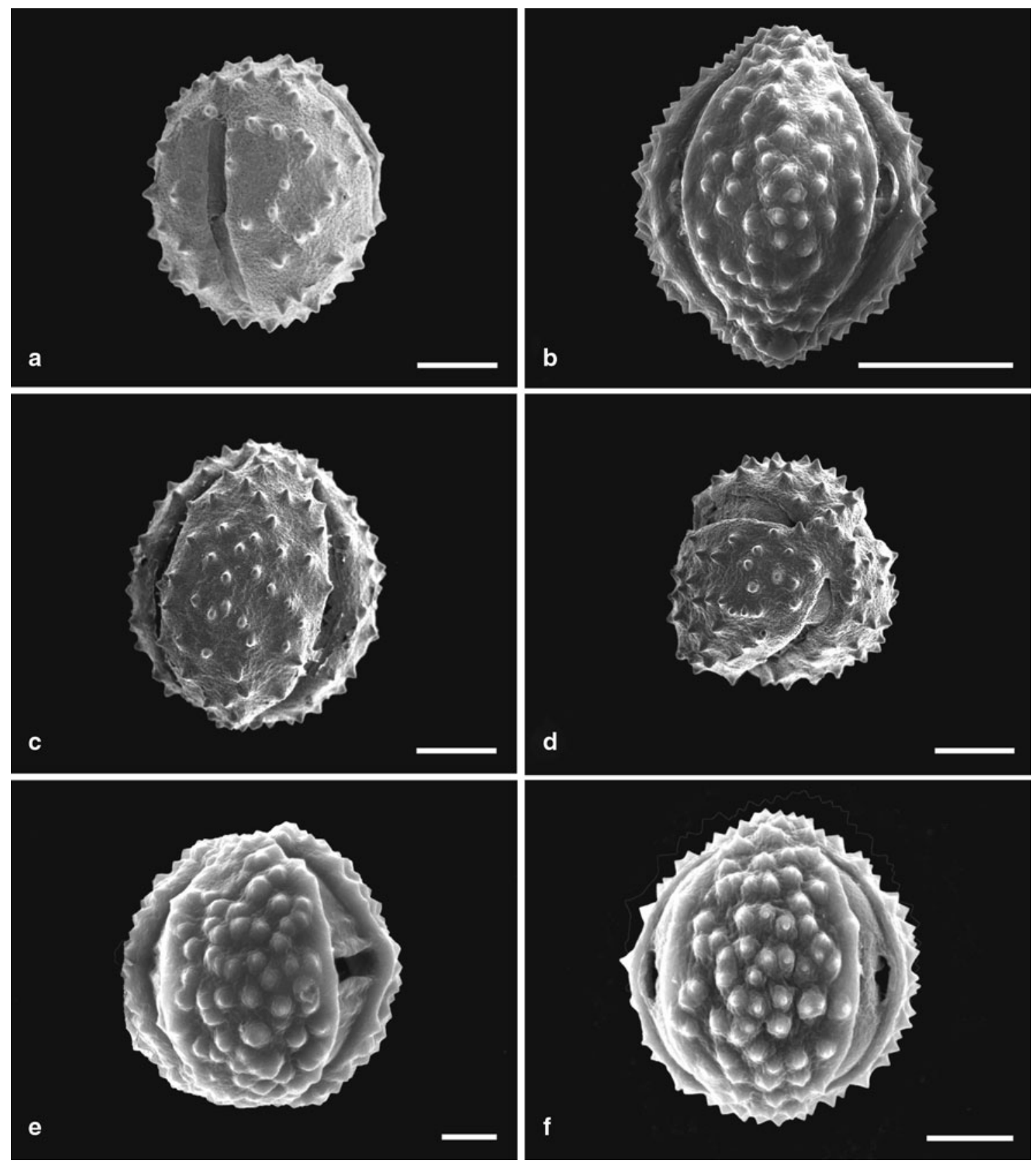

Fig. 4 SEM micrographs of pollen Type I showing the echinate pollen surface and features of apertures. a Anastraphia gomezii, equatorial view showing the colpus blunt ended. b Gochnatia vernonioides, equatorial view. c, d Anastraphia maisiana. c Equatorial

view showing the colpus with acute ends. d Tilted polar view. e Richterago discoidea, equatorial view showing a mesoaperture diffuse and the psilate apertural membrane. f $R$. conduplicata, equatorial view. Scale bars $\mathbf{a}-\mathbf{d}, \mathbf{f} 10 \mu \mathrm{m}$, e $5 \mu \mathrm{m}$

Anastraphia was recently restored from Gochnatia sect. Gochnatia on the basis of some distinctive morphological features (Ventosa and Herrera 2011a, b). The longer spines found in the echinate pollen surface of the Caribbean Anastraphia would support its recent resurrection, and is in agreement as well with Freire et al. (2002) who recognize this group as a different section of Gochnatia named Anastraphioides.

The pollen Type II, subtype IIa combines microechinate surface scarcely perforated medium pollen size and spheroidal-subspheroidal shape. These features are restricted to C. genistoides, one species of Anastraphia (A. attenuata), one species of Gochnatia sect. Hedraiophyllum (G. cordata) and all species of $G$. sect. Moquiniastrum. The exine surface features of pollen Type II subtype a clearly correspond to the Mutisia exine type (e.g., Katinas et al. 2008). 

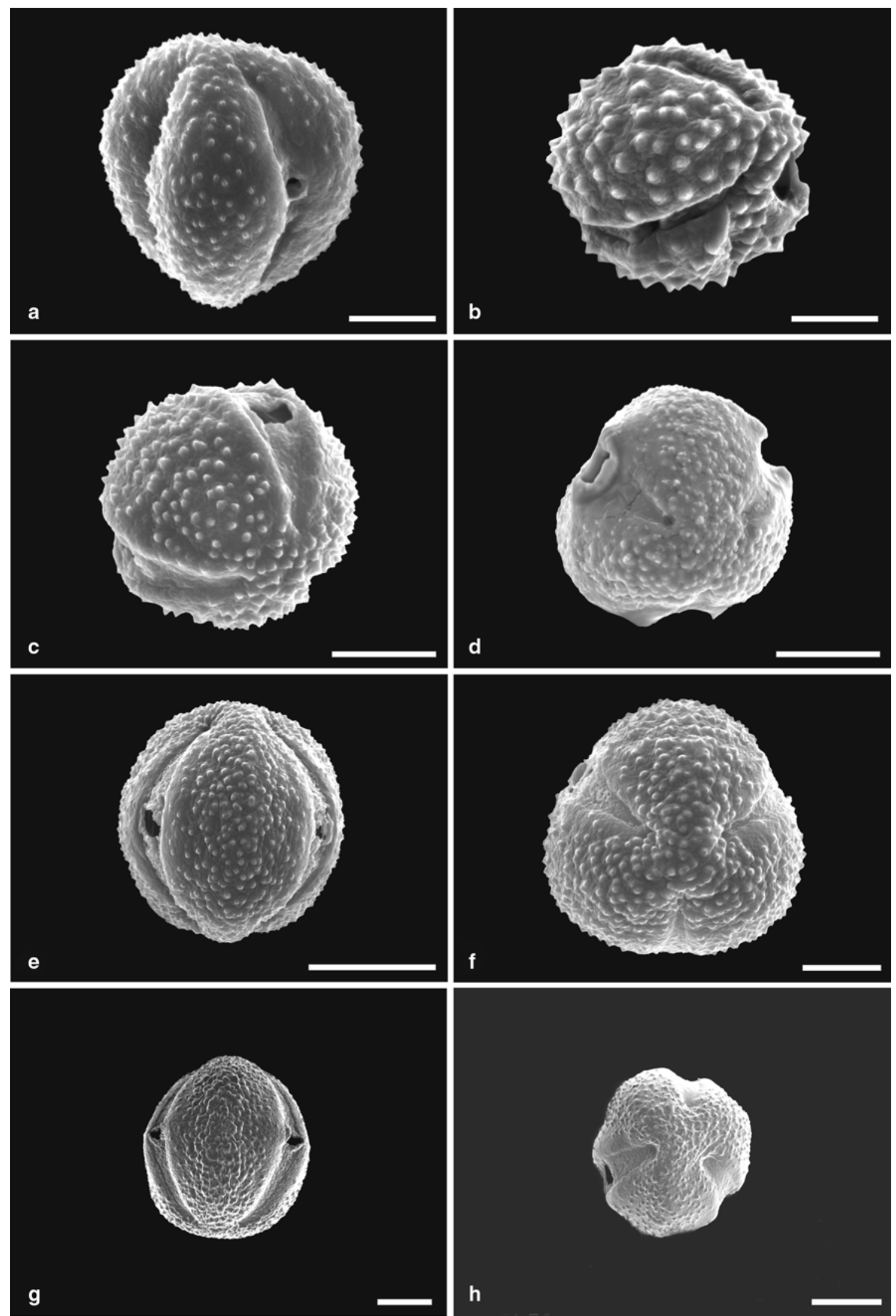
4 Fig. 5 SEM micrographs of pollen Type II and subtypes IIa and IIb showing the microechinate pollen surface and features of apertures. Subtypes IIa. a Gochnatia barrosoae tilted equatorial view, note the spiky microspines. b $G$. cordata tilted polar view, note the conical microspines. c $G$. oligocephala tilted polar view. Subtype IIb. d Nouelia insignis polar view showing small microspines. Subtype IIa. e, f Cyclolepis genistoides. e Equatorial view. f Polar view showing the colpi with acute ends. Subtype IIb. g, h Leucomeris spectabilis. $\mathbf{g}$ Equatorial view. h Polar view showing the colpi bluntended. Scale bars a-c, f $5 \mu \mathrm{m}, \mathbf{d}-\mathbf{e}, \mathbf{g}-\mathbf{h} 10 \mu \mathrm{m}$

The section Moquiniastrum is very peculiar within Gochnatia because of its distinctive morphological characteristic mainly of capitula and corollas (Sancho 2000). The observed pollen features reinforce the uniqueness of the section Moquiniastrum. On the other hand, pollen traits support taxonomic relationships between Gochnatia cordata (included in the section Hedraiophyllum by Cabrera 1971) and the section Moquiniastrum, as pointed out by Sancho (2000) and Freire et al. (2002).

The pollen Type II, subtype IIb, combines microechinate-rugulate exine surface, the large pollen size and the prolate shape, and characterizes the Asian genera Nouelia and Leucomeris. Thus, the pollen features support the recent molecular studies that recovered Leucomeris (once merged with Gochnatia) as closely related to Nouelia, but distantly related to Gochnatia. Within the microechinate pollen (pollen Type II), because of the subtle but significant variation in pollen sculpture, there may be continuous variation within subtypes. For instance, the pollen surface of $C$. genistoides apparently is an intermediate state between the microechinate pollen of Gochnatia sect. Moquiniastrum and Leucomeris and Nouelia (Fig. 5d, e). On the other hand, the pollen features of Anastraphia attenuata seem to be a transitional step between those occurring in Gochnatia sect. Gochnatia and $G$. sect. Moquiniastrum. The pollen of A. attenuata falls into Type II, but its surface is slightly echinate in comparison with the microechinate exine of most other species falling in that type (Fig. 5b). A. attenuata is the only species that falls into Type II, however, its slightly echinate surface would link this species with the other ones occurring in the Caribbean.

In addition, there is some correlation between the exine sculpture of the found pollen types and subtypes and the geographical distribution of the tribe Gochnatieae. The pollen with longest spines is notably well represented in the Caribbean species of Anastraphia as well as the species of the Brazilian Richterago. These findings are in agreement with the results of morphological phylogenetic analysis of Ventosa and Herrera (2011a) which shows close relationships between Richterago and Anastraphia. However, more recent molecular studies (Funk et al. in progress) indicate that most likely these pollen similarities are the result of parallel evolution.

Echinate pollen with a tendency to form polar caps and/ or equatorial thickness is present in some Andean species of Gochnatia such as G. arequipensis, and G. vernonioides. Slightly microechinate pollen is represented in the Asian genera Nouelia and Leucomeris, whereas conspicuously microechinate pollen, which characterizes Gochnatia sect. Moquiniastrum and Cyclolepis, is mainly represented in Brazil overlapping its distribution with Richterago, although somewhat extending to Argentina, Bolivia, Paraguay, Peru, and Uruguay.

The pollen features of Gochnatieae in the context of the basal grades of Compositae

The pollen diversity in the basal grades of Compositae (Panero and Funk 2008; Blackmore et al. 2009), except for Barnadesioideae Bremer and Jansen, revolves mainly around variations in the pollen surface (echinate or microechinate), the structure of the exine (i.e., degree of exine thickness) and the pollen size (generally medium to large). This context of overlapping characters makes difficult the distinction of the basal tribes based on their pollen features.

The pollen of tribe Gochnatieae shares some characteristics with most of the basal grades of Compositae (Panero and Funk 2008) as Hyalideae Panero, Mutisieae, Onoseridae (Benth.) Panero and Funk, Stifftieae D. Don, and Wunderlichieae Panero and Funk, including tricolporate aperture, surface covered by spines or microspines and acaveate exine (Anthemoid pattern sensu Skvarla et al. 1977). In the tribes mentioned above, the acaveate exine is the most important feature, and is shared by all the pollen types and subtypes. None of the pollen grains diverged from this basic wall stratification.

Within the basal grades of Compositae, except Barnadesioideae, the echinate pollen type occurs in the tribe Gochnatieae (e.g., Anastraphia, Cnicothamnus, most species of Gochnatia sect. Gochnatia and G. sect. Hedraiophyllum, Penthaphorus, and Richterago), tribe Hyalideae (Ianthopappus), Wunderlichieae (Wunderlichia Benth. and Hook. F.), and Stifftieae (e.g., Salcedoa F. Jiménez Rodr. and Katinas, Eurydochus Maguire and Wurdack and Gongylolepis R. H. Schomb.). In addition, they also share the prolate-subprolate shape and the large pollen size (Jiménez et al. 2004; Tellería 2008).

The microechinate pollen is clearly differentiated within the tribe Gochnatieae (e.g., Cyclolepis, Gochnatia section Moquiniastrum), and Hyalideae (Nouelia and Leucomeris) as well as many species of Mutisieae (e.g., Mutisia, Trichocline and Pachylaena), in which the microechinate surface is the most widespread sculpture type (Katinas et al. 2008). 

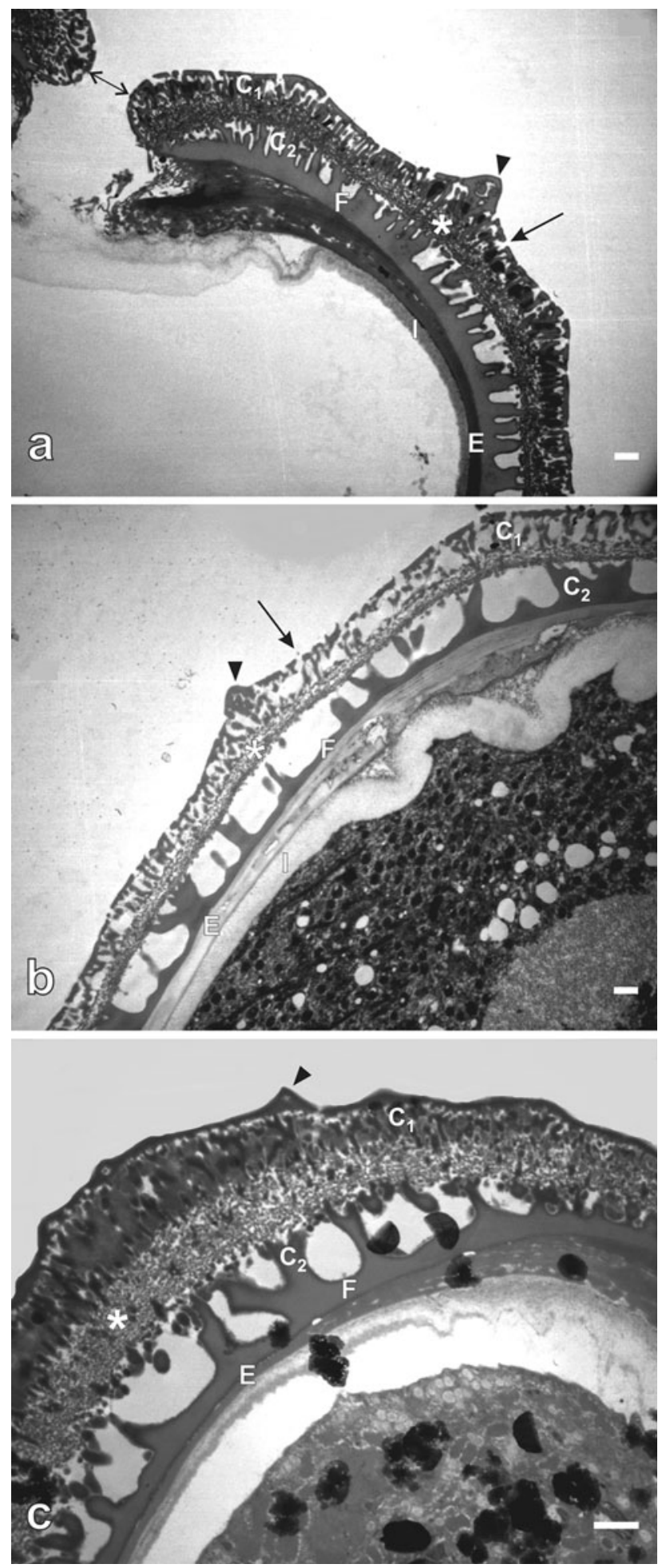

\section{Conclusions}

Our study of the pollen of a large number of species provided a better outlook of the variation of the pollen features in the tribe Gochnatieae. In addition, this survey allowed us to distinguish the characters of the sculpture and structure
4 Fig. 6 TEM micrographs of pollen showing: tectum perforations (arrow), spines and macrospines with apical channel (black arrowheads), ectoectexine $\left(C_{l}\right)$, internal tectum (asterisks), endoectexine $\left(C_{2}\right)$, foot layer $(F)$, endexine $(E)$ and intine $(I)$. a Anastraphia northropiana detail of exine section through mesocolpium and apertural region (double arrow). b Gochnatia oligocephala detail of exine section through mesocolpium. c Leucomeris spectabilis, imperforate tectum; some dark residual deposits of uranyl acetate can be observed on the cytoplasm, the endoectexine and the foot layer. Scale bars $1 \mu \mathrm{m}$

and to assess the taxonomic significance of the pollen types and subtypes. Thus, the conclusions of this work are the following.

1. Pollen features of the tribe Gochnatieae allowed us to distinguish two types of pollen on the basis of the shape and size of grains and the exine sculpture. The variation found in pollen features led us to recognize two new subtypes. However, the pollen types as well the subtypes did not always correspond to the limits of the studied genera.

2. The uniformity of the pollen features of Gochnatia sect. Moquiniastrum makes this section clearly distinguishable from the other ones within the genus. The morphological relationships between $G$. cordata and the section Moquiniastrum proposed by Sancho (2000) and Freire et al. (2002) are also supported by pollen features.

3. The pollen features of Anastraphia are in agreement with the findings of Freire et al. (2002) and Ventosa and Herrera $(2011 \mathrm{a}, \mathrm{b})$ in recognizing that group of species as a distinguishable entity.

4. The polyphyletic nature of the sect. Hedraiophyllum shown by both morphological and molecular studies (Cabrera 1971, as "unnatural"; Freire et al. 2002; Funk et al., in progress) is also supported by the pollen characters.

5. The pollen features of Pentaphorus and Gochnatia rotundifolia did not support their distinctiveness shown by other morphological evidence.

6. The pollen features shared across Cyclolepis, Ianthopappus, Leucomeris, Nouelia and Gochnatia sect. Moquiniastrum, as well as those shared by Richterago and the Anastraphia could be a result of parallel evolution.

Acknowledgments We are grateful to curators of the herbaria who lent us the specimens studied here. We are also grateful to SEM services of the Facultad de Ciencias Naturales y Museo de La Plata and Palynological Laboratory of the Swedish Museum of Natural History of Stockholm. Support was provided by Consejo Nacional de Investigaciones Científicas y Técnicas (CONICET), Argentina (PIP 02340) and Agencia Nacional de Promoción Científica y Tecnológica (PICT No. 01977). 


\section{Appendix}

Voucher material examined for the study of pollen. Superscripts refer to Table 1.

Anastraphia attenuata Britton: López Figueiras 2506 $(\mathrm{LP})^{(\mathrm{a})}$; Bisse et al. s/n 50424 (HAJB) $^{(\mathrm{b})}$. A. buchii Urb.: Jiménez \& Holdridge 2039 (US) ${ }^{(\mathrm{a})}$; Jiménez 3613 (LP); f8 (US) ${ }^{(b)}$. A. calcicola Britton: del Risco et al. $\mathrm{s} / \mathrm{n}^{\circ}$ (HAC 27561). A. crassifolia Britton: Arias et al. $\mathrm{s} / \mathrm{n}^{\circ}$ (HAJB 58526). A. cowellii Britton: Howard 5098 (US); Ventosa $\mathrm{s} / \mathrm{n}^{\circ}$ (HAJB). A. cubensis Carabia: López Figueiras 1692 (HAC). A. ekmanii Urb.: Ekman 13865 (S) ${ }^{(\mathrm{a})}$; Ekman 16865 (S). A. elliptica León: Valentín Montero 21269 (HAC). A. gomezii León: León 20876 (HAC). A. ilicifolia D. Don: Britton et al. 13981 (US) ${ }^{(a)}$; Bisse et al. $\mathrm{s} / \mathrm{n}^{\circ}$ $(\text { HAJB } 42105)^{(\mathrm{b})}$. A. intertexta Griseb.: Bisse et al. $\mathrm{s} / \mathrm{n}^{\circ}$ (HAJB 41557). A. mantuensis Griseb.: Shafer 11208 $(\mathrm{LP})^{(\mathrm{a})}$; Wright $2876(\mathrm{HAC})^{(\mathrm{b})}$. A. microcephala Griseb.: Ekman H-9280 (S). A. maisiana León: La Salle 17576 (HAC). A. montana Britton: Ekman 18725 (S). A. northropiana Combs.: Eggers $4473(\mathrm{C})^{(\mathrm{a})}$; Small \& Carter 8526 (US); Ventosa, Oviedo \& Fuentes (HAC 42615). A. obovata Urb. \& Ekman: Ekman 5366 (S) A. obtusifolia Britton: Acuña \& Díaz Barreto 17456 (HAC). A. parvifolia Britton: Bisse et al. s/n (HAJB 38075). A. pauciflosculosa Hitchcock: Eggers $3866(\mathrm{C})^{(\mathrm{a})}$; Brace 4019 (US). A. picardae Urb.: Ekman 5385 (US). A. recurva Britton: Bisse et al. $\mathrm{s} / \mathrm{n}^{\circ}$ (HAJB 21657); Alvarez et al. $\mathrm{s} / \mathrm{n}$ (HAJB 56472) ${ }^{(a)}$; Acuña 12788 (US). A. shaferi Britton: Bisse et al. s/n (HAJB 35368). A. tortuensis Urb.: Ekman H-4313 (S).

Cnicothamnus lorentzii Griseb.: Maldonado 408 (LP) ${ }^{(\mathrm{a})}$; Cabrera et al. 14497 (LP). Cyclolepis genistoides D. Don: Zardini and Kiesling 114 (LP) ${ }^{(\mathrm{a})}$; Ruiz Leal 4055 (LP). G. arborescens Brandegee:, Keid Moran 9538 (US); Spjut and Edson 6085 (US). G. argyrea (Dusén) Cabrera: Smith et al. 14460. G. arequipensis Sandw.: Eyerden \& Beetle

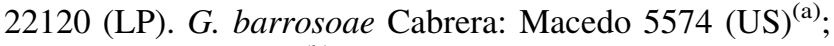
Cabrera 12313 (LP) ${ }^{(\mathrm{b})}$, Mantovani 503 (LP); Mathes 3 (LP). G. boliviana S. F. Blake: Beck 6264 (LP) ${ }^{(\mathrm{a})}$; Herzog

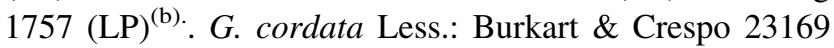
$(\mathrm{LP})^{(\mathrm{a})} ; 19951$ (US) $^{(\mathrm{b})}$. G. curviflora (Griseb.) O. Hoffm.: Jerez et al. 4912 (LP); Fiebrig s/n ${ }^{\circ}$ (C). G. densicephala (Cabrera) G. Sancho: Assis \& Williams 7393 (LP) ${ }^{(a)}$; Glaziou 11072 (K). G. discolor Baker: Claussen 1301 (NY). G. floribunda Cabrera: Roque et al. 281 (LP). G. gardneri (Baker) Cabrera: Gardner 4183 (G). G. hatschbachii Cabrera: Maguire et al. 49149 (US). G. haumaniana Cabrera: Maguire et al. 49194 (US), Rojas 10391 (K). G. magna Cabrera: Cronquist 11277 (NY). G. oligocephala (Gardner) Cabrera: Menezes $\mathrm{s} / \mathrm{n}^{\circ}$ (59198 LP). G. orbiculata (Malme) Cabrera: Handro 156 (US). G. palosanto Cabrera: Ventura $9793(\mathrm{LP})^{(\mathrm{a})}$; Wood 12696
(US) ${ }^{(\mathrm{b})}$. G. patazina Cabrera: Velande Nuñez 3178 (LP). G. polymorpha (Less.) Cabrera: Harley et al. 26497 (US) ${ }^{(a)}$; Woolston $808(\mathrm{~S})^{(\mathrm{b})}$; Blanchet 3251 (LP); Glaziou 3039 (LP). G. ramboi Cabrera: Rambo 51161 (LP). G. rotundifolia Less.: Hoehne 3411273 (US) ${ }^{(\mathrm{a})}$; Brade 5346 (S). G. vernonioides Kunth.: López et al. 3354 (LP) ${ }^{(\mathrm{a})}$; Becker \& Torrones 1391 (US); López Sagástegui 3354 (LP). Ianthopappus corymbosus (Less.) Roque \& D. N. J. Hind: Palacio-Cuezzo 2304 (LP). Leucomeris spectabilis D. Don: Wallich 1018 (C) ${ }^{(\mathrm{a})}$; Nicolson 3254 (US), Galvola 37 (LP); Nouelia insignis Franch.: Rock 11714 (US) ${ }^{(\mathrm{a})} ; 24253$ (US) $^{(\mathrm{b})}$. Pentaphorus foliolosus D. Don: Boelcke 3887 (LP) $^{(\text {a) }}$; Marticorena et al. 25217 (LP) ${ }^{\text {(b) }}$; Jiles 1693 (S). P. glutinosus D. Don: Simon \& Bonifacino 509 (LP) ${ }^{(\mathrm{a})}$; Navarro \& Bruno $9228(\mathrm{~S})^{(\mathrm{b})}$. Richterago amplexifolia (Gardner) Kuntze: Anderson et al. 35940 (US) ${ }^{(a)}$; Almeida et al. 140 (ALBC); R. angustifolia (Gardner) Roque: Roque et al. 1634 (ALCB). $R$. arenaria (Baker) Roque: Roque et al. 1646 (ALCB). $R$. caulescens Roque: Roque \& Hervencio 440 (US); Roque et al. 1625 (ALCB). $R$. conduplicata Roque: Roque et al. 1636 (ALCB). R. discoidea (Less.) Kuntze: King et al. 8167 (US) ${ }^{(\mathrm{a})}$; Roque et al. 1900 $(\mathrm{ALCB})^{(\mathrm{b})}$; Warming $\mathrm{s} / \mathrm{n}^{\circ}(\mathrm{C}) . R$. elegans Roque: Roque et al. 1648 (ALCB). R. polyphylla (Baker) Ferreira: Hatschbach et al. 69634 (ALCB). R. radiata (Vell.) Roque: Smith et al. 14790 (US) ${ }^{(a)}$; Hatschbach 1872 (LP); Almeida 283 et al. $(\mathrm{ALCB})^{(\mathrm{b})}$. R. stenophylla (Cabrera) Roque: Roque et al. 1626 (ALCB).

\section{References}

Acevedo-Rodríguez, P \& MT Strong (2007) Catalogue of the seed plants of the West Indies Website http://botany.si.edu/antilles/ WestIndies/acknowledgments.htm [August 2012]

Blackmore S, Wortley AH, Skvarla JJ, Robinson H (2009) Evolution of pollen in Compositae. In: Funk VA, Susanna A, Stuessy T, Bayer R (eds) Systematic, evolution and biogeography of the compositae. IAPT, Viena

Bremer K (1994) Asteraceae: cladistics and classification. Timber Press, Portland

Cabrera AL (1971) Revisión del género Gochnatia (Compositae). Revista del Museo de La Plata, Sección Botánica 12:1-160

Cabrera AL (1977) Mutisieae—systematic review. In: Heywood VH, Harborne JB, Turner BL (eds) The biology and chemistry of the Compositae, vol 1. Academic Press, London, pp 1039-1066

Erdtman G (1960) The acetolysis methods, a revised description. Svenk Botanisk Tidskrift 54:561-564

Erdtman G (1969) Handbook of palynology. An introduction to the study of pollen grains and spores. Copenhagen: Munksgaard/ Hafner

Freire SE, Katinas L, Sancho G (2002) Gochnatia (Asteraceae, Mutisieae) and the Gochnatia complex: taxonomic implications from morphology. Ann Mo Bot Gard 89:524-549

Hind N (2007) Tribe Mutisieae. In: Kubitzki K (ed) The families and genera of vascular plants, vol 8. Springer, Berlin and Heidelberg, pp $90-123$ 
Jiménez F, Katinas L, Tellería MC, Crisci JV (2004) Salcedoa gen. nov, a biogeographic enigma in the Caribbean Mutisieae (Asteraceae). Syst Bot 29:987-1002

Katinas L, Prusky J, Sancho G, Tellería MC (2008) The subfamily Mutisioideae (Asteraceae). Bot Rev 74:469-716

Lin NN, Wang H, Li DZ, Blackmore S (2005) Pollen morphology in eight genera of the subtribe Mutisiinae Less. Sensu Bremer (Compositae) from Asia. J Integr Plant Biol 47:1036-1046

Ortíz S, Bonifacino M, Crisci JV, Funk V, Hansen HV, Hind DJN, Katinas L, Roque N, Sancho G, Susanna A, Tellería MC (2009) The basal grade of Compositae: Mutisieae (sensu Cabrera) and carduoideae. In: Funk VA, Susanna A, Stuessy T, Bayer R (eds) Systematic, evolution and biogeography of the Compositae. IAPT, Viena

Panero JL, Funk V (2002) Toward a phylogenetic subfamilial classification for the Compositae (Asteraceae). Proc Biol Soc Wash 115:909-922

Panero JL, Funk V (2008) The value of sampling anomalous taxa in phylogenetic studies: major clades of the Asteraceae revealed. Mol Phylogenet Evol 47:757-782

Parra O, Marticorena C (1972) Granos de pollen de plantas chilenas II Compositae-Mutisieae. Gayana 21:1-107

Punt WS, Hoen PP, Blackmore S, Nilsson S, Le Thomas A (2007) Glossary of pollen and spores terminology. Rev Palaeobot Palynol 143:1-81

Roque N, Hind DJN (2001) Ianthopappus, a new genus of the tribe Mutisieae (Compositae). Novon 11:97-101

Roque N, Pirani JR (2001) Reinstatement of the name Richterago Kuntze and recircumscription of the genus to include species formerly treated as Actinoseris (Endl.) Cabrera (Compositae, Mutisieae). Taxon 50:1155-1160

Roque N, Silvestre-Capelato MSF (2001) Generic delimitation of Gochnatia, Richterago and Ianthopappus (Compositae-Mutisieae) based on pollen morphology. Grana 40:197-204
Sancho G (2000) Revisión y filogenia de la sección Moquiniastrum del género Gochnatia Kunth (Asteraceae, Mutisieae). Fontqueria 54:61-122

Sancho G, Freire SE (2009) Gochnatieae (Gochnatioideae) and Hyalideae (Wunderlichioideae p.p). In Systematic evolution and biogeography of the Compositae, Funk VA, Susanna, A, Stuessy T, Bayer, R (eds), IAPT, Viena, Austria

Skvarla JJ, Turner BL, Patel VC, Tomb AC (1977) Pollen morphology in the Compositae and in morphologically related families. In: Heywood V, Harborne JB, Turner BL (eds) The Biology and chemistry of the Compositae. Academic Press, London, pp $141-248$

Tellería MC (2008) Taxonomic significance of pollen types in the Guyana highland-—centred genera (Asteraceae, Mutisioideae). Bot J Linn Soc 156:327-340

Tellería MC, Forcone A (2002) Morfología del pollen de las mieles del valle de Río Negro, Valle inferior del río Chubut y llanura del río Sengerr. Boletín de la Sociedad Argentina de Botánica 37:235-250

Tellería MC, Katinas L (2004) A comparative palynologic study of Chaetanthera (Asteraceae, Mutisieae) and allied genera. Syst Bot 29:752-772

Tellería MC, Katinas L (2009) New insights into the pollen morphology of the genus Mutisia (Asteraceae, Mutisieae). Plant Syst Evol 280:229-241

Ventosa I, Herrera P (2011a) Do the Antillean species of Gochnatia Kunth (Asteraceae) truly belong in that genus? A phylogenetic analysis based on morphological characters. Compositae Newsl 49:8-22

Ventosa I, Herrera P (2011b) Restoration of the name Anastraphia to define the species in the section Anastraphioides of Gochnatia (Gochnatioideae, Asteraceae). Compositae Newsl 49:23-37

Zao Z, Skvarla JJ, Hansen RK (2006) Mutisieae (Asteraceae) pollen ultrastructure atlas. Lundellia 9:51-76 